\title{
Relationship between Profile of Mango Growers with Level of Awareness and Extent of Adoption about Value Added Techniques
}

\author{
Snehal Patel ${ }^{1 *}$ and Payal Patel ${ }^{2}$ \\ Department of Extension Education, N.M.College of Agriculture, NAU, Navsari, India \\ *Corresponding author
}

\begin{tabular}{|l|}
\hline Ke y w or d s \\
Awareness, \\
Adoption, Food \\
processing
\end{tabular}

\section{A B S T R A C T}

Horticulture crop production has moved from rural confines to commercial ventures and has attracted youth since it has proved to be intellectually satisfying and economically rewarding. Intensifying horticulture has been boosted up by the diversification. In the present days, the food processing sectors play the significant role in diversification of horticultural produce. The present study was conducted in Navsari district of Gujarat in order to ascertain the relationship between selected profile of mango growers with awareness and adoption about value added techniques. A total of 100 mango growers were selected as respondents from ten selected villages of two talukas of Navsari district. The findings of this study reveal that the variable like education, farming experience, social participation, extension contact, market orientation, and scientific orientation of mango growers were found positive and significant association with the level of awareness about value added techniques. While, the variable like education, annual income, social participation, extension contact and economic motivation of mango growers were found positive and significant association with the level of adoption about value added techniques.

\section{Introduction}

The changing scenario encourages private investment, to go for hi-tech horticulture with micro-propagation, protected cultivation, drip irrigation, fertigation, and integrated nutrient and pest management, besides making use of latest post-harvest measures particularly in the case of perishable commodities. As a result, horticulture crop production has moved from rural confines to commercial ventures and has attracted youth since it has proved to be intellectually satisfying and economically rewarding. For economically benefits, horticultural commodities must be competitive both in quality and price.

To study a relationship between selected characteristics and level of awareness and extent of adoption of mango growers regarding value added techniques. 


\section{Materials and Methods}

An ex-post-facto research design was used in the present investigation. The study was conducted during April-May 2018 in Navsari district of Gujarat state. The main focus of the investigation is on awareness and adoption of farmers towards value added techniques. Navsari district has six talukas. Out of six talukas, two talukas Navsari and Vansda were selected purposively considering highest number of mango cultivation. Five villages were purposively selected from each selected taluka considering highest number of mango growers. Thus, the total number of villages for the study was ten. Ten farmers were selected randomly from each village and thus, the 100 farmers were selected as respondents. Twelve independent variables of the fruit growers were measured through respective scales with due modification.

\section{Results and Discussion}

The table 1 indicates that the variable like education, farming experience, social participation, extension contact, market orientation, and scientific orientation of mango growers were found positive and significant association with the level of awareness about value added techniques. But age, size of family, land holding, area under mango crop, annual income and economic motivation had not found any relationship. This indicate that there was significant influence of education on awareness of mango growers regarding value added techniques.

Table.1 Relationship between selected characteristics and level of awareness and extent of adoption of mango growers

$(n=100)$

\begin{tabular}{|c|c|c|c|}
\hline \multirow{2}{*}{$\begin{array}{l}\text { Sr. } \\
\text { No. }\end{array}$} & \multirow[t]{2}{*}{ Personal characteristics } & \multicolumn{2}{|c|}{ Correlation coefficient $(r)$} \\
\hline & & Awareness & Adoption \\
\hline 1 & Age & 0.240 & -0.009 \\
\hline 2 & Education & $0.371 * *$ & 0.200* \\
\hline 3 & Size of family & 0.217 & 0.239 \\
\hline 4 & Farming experience & $0.289 * *$ & 0.196 \\
\hline 5 & Land holding & 0.392 & 0.225 \\
\hline 6 & Area under mango crop & 0.272 & 0.200 \\
\hline 7 & Annual income & 0.201 & $0.232 *$ \\
\hline 8 & Social participation & $0.196^{*}$ & $0.243 *$ \\
\hline 9 & Extension contact & $0.199 *$ & $0.302 * *$ \\
\hline 10 & Market orientation & $0.201 *$ & 0.207 \\
\hline 11 & Economic motivation & 0.185 & $0.278 * *$ \\
\hline 12 & Scientific orientation & $0.224 *$ & 0.038 \\
\hline
\end{tabular}

* Significant at 5\%,** Significant at $1 \%$

The table 1indicate that the variable like education, annual income, social participation, extension contact and economic motivation of mango growers were found positive and significant association with the level of adoption about value added techniques. But age, size of family, land holding, area under mango crop, market 
orientation and scientific orientation had not found any relationship. This indicates that there was significant influence of education on adoption of mango growers regarding value added techniques.

In conclusion, the findings of this study reveal that the variable like education, farming experience, social participation, extension contact, market orientation, and scientific orientation of mango growers were found positive and significant association with the level of awareness about value added techniques. While, the variable like education, annual income, social participation, extension contact and economic motivation of mango growers were found positive and significant association with the level of adoption about value added techniques.

\section{References}

Makarau Shehu Bako, AyubaDamina, Mohammed Ibrahim Daneji and Anna Ogilvie Garba. (2013). Socio-economic factors influencing the adoption of ginger farming technologies in Samaru zone of the Kaduna state Agricultural Development Project (KADP). International Journal of Humanities and Social Science Invention. 2 (7): PP.39-44.

Mehta B. M. and Madhuri Sonawane (2012). Characteristic and adoption behaviour of mango growers of Valsad district of Gujarat. Agric. Update, 7(1\&2): 37-41.

Modi, R. D. (2010). A study on knowledge and adoption of post-harvest management practices among the mango growers of northern Karnataka. M.Sc. (Agri.) Thesis. University of Agricultural Science, Dharwad.

\section{How to cite this article:}

Snehal Patel and Payal Patel. 2020. Relationship between Profile of Mango Growers with Level of Awareness and Extent of Adoption about Value Added Techniques. Int.J.Curr.Microbiol.App.Sci. 9(01): 1392-1394. doi: https://doi.org/10.20546/ijcmas.2020.901.153 